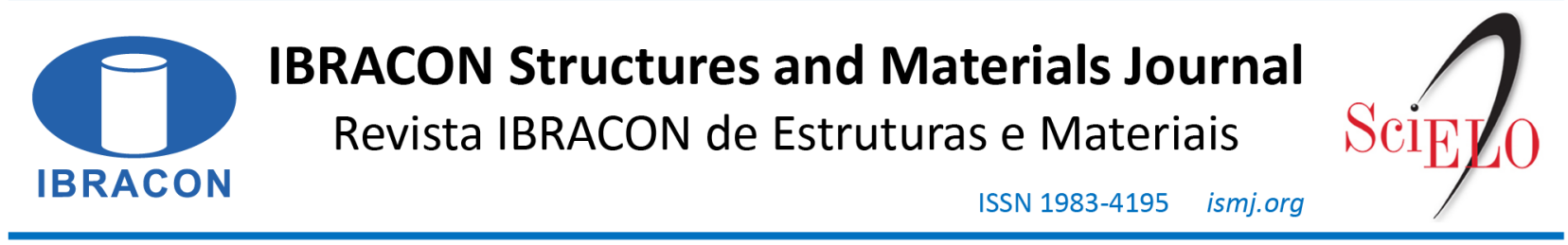

ORIGINAL ARTICLE

\title{
Residual strength of reinforced concrete stub columns subject to moderate temperatures
}

\section{Resistência residual de colunas curtas de concreto armado submetidas a temperaturas moderadas}

\author{
Eduardo Henrique Barros Lima ${ }^{\mathrm{a}}$ \\ Daniel Carlos Taissum Cardoso ${ }^{\mathrm{a}}$
}

${ }^{\text {aP }}$ ontifícia Universidade Católica do Rio de Janeiro - PUC-Rio, Departamento de Engenharia Civil e Ambiental, Rio de Janeiro, RJ, Brasil

Received 24 January 2020

Accepted 21 August 2020

\begin{abstract}
This work aims to evaluate the residual strength of reinforced concrete stub columns subjected to moderate temperatures. To accomplish this task, an experimental program was carried out including compression tests on plain concrete specimens exposed to temperatures up to $600{ }^{\circ} \mathrm{C}$ and on reinforced concrete stub columns with two different tie configurations heated at a constant rate for up to $120 \mathrm{~min}$. The results show a loss of residual compressive strength with temperature and the beneficial influence of ties to prevent the spalling phenomenon, although samples with more ties exhibited lower capacity. Finally, the results were compared to the analytical prediction using a cross-sectional approach with idealized stress-strain relations, showing a good correlation. The applicability of the Isotherm $500{ }^{\circ} \mathrm{C}$ method is discussed for moderate temperatures.
\end{abstract}

Keywords: residual strength, columns, reinforced concrete, moderate temperatures.

Resumo: O presente trabalho tem como objetivo avaliar a resistência residual de colunas curtas de concreto armado submetidas a temperaturas moderadas. Para isso, foi realizado um programa experimental incluindo ensaios de compressão em corpos-de-prova cilíndricos de concreto simples de $5 \times 10 \mathrm{~cm}$ submetidos a temperaturas de até $600{ }^{\circ} \mathrm{C}$ e de colunas curtas de concreto armado de $15 \times 30 \mathrm{~cm}$ com duas diferentes configurações de estribos e submetidos a distintos tempos de exposição de até 120 min sob uma taxa de aquecimento constante. Os resultados comprovam a perda de resistência residual à compressão com a temperatura e a influência benéfica dos estribos na prevenção do fenômeno de spalling, embora amostras com mais estribos tenham apresentado menor resistência. Por fim, os resultados foram comparados a previsão analítica utilizando abordagem seccional com diagramas tensão-deformação idealizados, tendo apresentado boa correlação. A aplicabilidade do método da isoterma $500{ }^{\circ} \mathrm{C}$ é discutida para temperaturas moderadas.

Palavras-chave: resistência residual, colunas, concreto armado, temperaturas moderadas.

How to cite: E. H. B. Lima and D. C. T. Cardoso, "Residual strength of reinforced concrete stub columns subject to moderate temperatures," Rev. IBRACON Estrut. Mater., vol. 14, no. 3, e14311, 2021, https://doi.org/10.1590/S1983-41952021000300011

\section{INTRODUCTION}

Concrete is known for its good fire performance due its low thermal conductivity and due to the fact that is incombustible and does not exhale toxic gases when exposed to high temperatures [1]. However, the heterogeneous nature of the concrete and the uncertainties associated with the nature of the fire and its corresponding thermal loading make the interaction between material and loading very complex [2]. Despite this, it is known that the exposure to high temperatures can lead to physical-chemical transformations in the cement paste such as the decomposition of ettringite, evaporation of free water, lamellar and adsorbed water, detachment of water chemically linked to CSH crystals (dehydration), as well as crystal dehydration and differential expansion

Corresponding author: Daniel Carlos Taissum Cardoso. E-mail: dctcardoso@puc-rio.br

Financial support: This study was financed in part by the Coordenação de Aperfeiçoamento de Pessoal de Nível Superior (CAPES) - Finance code 001 - and by Brazilian agencies FAPERJ and CNPq.

Conflict of interest: Nothing to declare. 
of non-hydrated components. In addition, the aggregates can also undergo changes due to their state of humidity, permeability and nature and the paste-aggregate interface can degrade due to incompatibility between the thermal properties of the two constituents, forming micro cracks [1], [3]-[5]. As a consequence of these transformations, concrete may experience changes in its physical-chemical-mechanical properties, which include reduction of density, variation of specific heat and thermal conductivity and reduction of compression strength and modulus of elasticity. These changes are influenced by the time of exposure to fire, the maximum temperature reached, the heating/cooling speed and the concrete mix. However, the porosity and initial humidity also play an important role in the behavior, since the water trapped in the pores can lead to the development of pore-pressure, with the consequent appearance of tensile stresses that cause the detachment (or debonding) of the concrete - spalling. This phenomenon may also occur as a consequence of the introduction of thermal stresses associated in restrained structural members or in structures subjected to high thermal gradients [6]. Spalling is more severe in highstrength concretes, which are characterized by a lower porosity and permeability, and the use of fibers has been seen as an interesting alternative to mitigate the problem [7]-[9].

The steel used for reinforcement can also undergo significant loss of strength when heated. Although the behavior depends on the type of steel used and the heating conditions, the original performance can be recovered after cooling if the maximum temperature reached is less than $450{ }^{\circ} \mathrm{C}$ for cold rolled steel and $600{ }^{\circ} \mathrm{C}$ for hot rolled steel. There is a consensus in the literature that the properties of steel used as passive reinforcement are almost completely recovered after a heating cycle at $500{ }^{\circ} \mathrm{C}$. At higher temperatures, the strength of the steel should be properly assessed [10], [11].

In reinforced concrete structures, the behavior in a fire situation is controlled by the history of multiaxial stress states, by the temperature distribution and by the moisture content in the structure [12]. A first significant effect on the behavior is the loss of bond between steel and concrete for temperatures above $150{ }^{\circ} \mathrm{C}$, affecting the material's composite behavior [13]-[15]. For higher temperatures, the coefficient of thermal expansion of concrete - initially similar to that of steel - undergoes variations, leading to differential expansions that further affect the bond between materials and produce stresses that cause the concrete to breakdown, crack and delaminate, exposing the reinforcement to fire [12]. These cracks can ultimately contribute to the heating of steel bars, which can increase differential thermal expansion and, consequently, cracking. According to Chung and Consolazio [16], the presence of steel bars influences the transport of water inside the heated concrete, creating clogging areas that can increase the risk of spalling. However, the water retention around the bars alters the heat transmission, tending to reduce the temperature inside the concrete. The spalling effect on reinforced concrete members can be mitigated through the use of ties [6], [17]. The ties also contribute to increase the compressive strength and deformation capacity of concrete in the confined region [17]-[19].

Several tests on reinforced concrete columns with different geometries have been reported in the literature [17], [18], [20]-[25]. In general, tests are performed using standard ISO 834 fire curves [26] and losses in strength and stiffness and failure modes are usually presented. There is also a wide range of methods to predict the performance of structural members, including numerical [26]-[33] and those recommended by Eurocode 2, Part 1-2 [34], which include, for example, the simplified zone and $500{ }^{\circ} \mathrm{C}$ isotherm methods. It is worth mentioning that the latter considers that the strength of the structural element can be determined considering the original properties of the concrete for the regions subjected to temperatures below $500{ }^{\circ} \mathrm{C}$. Finally, in addition to obtaining the constitutive laws, one of the biggest challenges for obtaining analytical solutions is the prediction of the temperature profile in the cross section. In this regard, different advanced and simplified heat transfer models are also described in the literature [35]-[37].

In some fire situations, the structures do not always reach severe temperatures, such as those in the range of 1000 to $1200^{\circ} \mathrm{C}$ specified in the standard fire curves of ISO 834 [26], and there may be cases in which the fire load/ventilation is low, with a much softer heating ramp. In this regard, it is worth highlighting the following points

a) the temperature reached by the gas and the heating rate depend on a series of parameters, such as the thermo-physical properties of the compartment surface, ventilation characteristics (openings), protection measures and specific fire load. The parametric standard fire curve of Eurocode 1, Part 1-2 [38] offers the possibility of considering these parameters for design;

b) in the case of localized fires, the gas temperature decreases with distance to the focus (far field), depending on the size of the fire [39]-[41];

c) the results of fire tests carried out in the literature vary considerably in the results [40], [41]. The Tisova test with mobile fire, for example, points out that columns reached temperatures below $200^{\circ} \mathrm{C}$ and a heating rate of $1{ }^{\circ} \mathrm{C} / \mathrm{min}[42]$. 
Results of recent simulations in concrete frames in different fire conditions also point out that the temperatures in the reinforcements were below $500{ }^{\circ} \mathrm{C}$ [43].

Even so, once the fire has ceased, it is necessary to evaluate the residual strength of the structural members, so that it can be decided for its strengthening or demolition of the structure. However, standards, design recommendations and studies in the literature usually address verification in high temperatures, where the impacts on the structure are undeniable. The decisions to be made by the engineer require rigorous evaluation, taking into account aspects of cost and safety and, therefore, the consideration of conservative scenarios in terms of safety will result in interventions with higher costs. In this context, it is noteworthy that there are few experimental results on short reinforced concrete columns subjected to moderate temperatures and, although the beneficial effects of using ties to increase ductility, residual capacity and spalling prevention have been reported in the literature, the results are still limited to specific cases of temperature or to higher concrete strength classes [44]-[46].

This work aims to evaluate the behavior and residual strength of reinforced concrete columns subjected to moderate temperatures, based on an experimental program focused on structural members fabricated with low mechanical strength concrete, with two different tie configurations. The columns are subjected to moderate thermal loading rates, seeking to reproduce mild fire conditions, as previously mentioned. The consideration of low-strength concretes aims to simulate the material of historic and old buildings, which usually exhibit a greater risk of fire [47]. In fact, at the same time that these buildings are more prone to fire, low-strength concretes have a better behavior with respect to spalling. Finally, the experimental results are compared with analytical predictions using the residual constitutive relationships of the materials and, further, discussed in the light of the $500{ }^{\circ} \mathrm{C}$ isotherm method.

\section{MATERIALS AND METHODS}

The experimental program adopted in this research aims to evaluate the residual compressive strength of reinforced concrete exposed to moderate temperatures. To accomplish this task, the experimental program was divided into two stages:

- Stage I: residual characterization tests of simple concrete and steel bars for different temperatures (control);

- Stage II: compression tests on reinforced concrete cylindrical members with two different tie configurations and subjected to slow thermal loading, considering different exposure times.

The materials used for the casting of concrete specimens consist of siliceous aggregates (coarse and fine), cement and water. The coarse aggregate used was gravel $\# 0(9.5 \mathrm{~mm})$ while the fine aggregate came from dry river sand. The cement used was of the Brazilian CPII-E-32 type and the water used to manufacture the concretes was obtained from the local supply system. The proportions used for making the concrete specimens, in mass, were 1:3.05:2.86:0.83 (cement:sand:gravel:water) in both stages. The anticipated compressive strength was $20 \mathrm{MPa}$, with the purpose to study a relatively low strength concrete. The specimens for the different tests were prepared in the laboratory, demoulded after 24 hours and stored under a humid blanket for 28 days, before testing. For steel, $10 \mathrm{~mm}$ diameter Brazilian CA-50 steel ribbed bars were used, with yield strength of $500 \mathrm{MPa}$ and elastic modulus of approximately $200 \mathrm{GPa}$.

\subsection{Stage I}

In this stage, eight plain concrete cylindrical specimens of $5 \mathrm{~cm}$ in diameter and $10 \mathrm{~cm}$ in height were tested, divided into four groups, according to the peak temperature considered: ambient $\left(20^{\circ} \mathrm{C}\right.$, for control), $200^{\circ} \mathrm{C}, 400{ }^{\circ} \mathrm{C}$ and $600{ }^{\circ} \mathrm{C}$. The equipment used for heating the specimens was an electric furnace with a maximum capacity of $1000^{\circ} \mathrm{C}$ from the SP Labor - SP1200 brand, as shown in Figure 1a. The specimens were thermally loaded at an average rate of $10^{\circ} \mathrm{C} / \mathrm{min}$ to the desired temperature, being exposed for an additional 30 minutes at constant temperature. After heating, the specimens were removed from the oven and cooled to room temperature. This procedure was adopted to avoid thermal gradients associated with sudden cooling. Table 1 presents a summary of the tests with the appropriate nomenclatures adopted in this stage to identify the specimens. The parameters related to the results, also presented in the table, will be described in Section 3.1. 


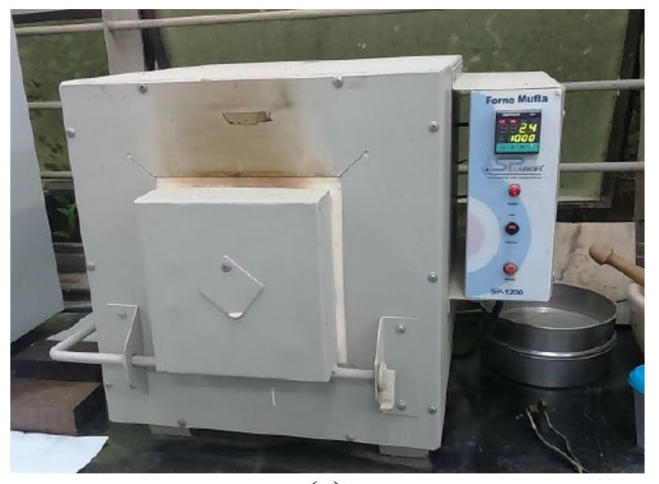

(a)

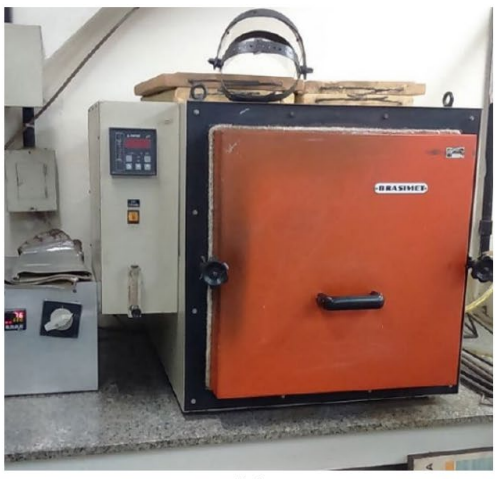

(b)

Figure 1. Eletric furnaces used in the experimental program: a) Stage I; b) Stage II.

Table 1. Identification (ID) of specimens for Stage I and summary of results.

\begin{tabular}{|c|c|c|c|c|c|c|c|c|}
\hline \multirow{2}{*}{ ID } & Temperature & $f_{\mathrm{c} \theta}$ & $f_{\mathrm{c} \theta \text {,mean }}$ & $\left(f_{\mathrm{c} 20}-f_{c \theta}\right) / f_{\mathbf{c} 20}$ & $\varepsilon_{c 1, \theta}$ & $E_{c s \theta}$ & $E_{\mathrm{cs} \theta \text {,mean }}$ & $\left(E_{\mathrm{cs} 20}-E_{c s}\right) / E_{\mathrm{cs} 20}$ \\
\hline & $\left({ }^{\circ} \mathrm{C}\right)$ & (MPa) & (MPa) & - & - & (GPa) & (GPa) & - \\
\hline CP1_20 & \multirow{2}{*}{ Ambient } & 19.2 & \multirow{2}{*}{19.1} & \multirow{2}{*}{-} & \multirow{2}{*}{0.0033} & 19.5 & \multirow{2}{*}{19.4} & \multirow{2}{*}{-} \\
\hline CP2_20 & & 19.0 & & & & 19.4 & & \\
\hline CP1_200 & \multirow{2}{*}{200} & 17.1 & \multirow{2}{*}{16.1} & \multirow{2}{*}{$16 \%$} & \multirow{2}{*}{0.0032} & 11.9 & \multirow{2}{*}{11.1} & \multirow{2}{*}{$43.0 \%$} \\
\hline CP2_200 & & 15.2 & & & & 10.2 & & \\
\hline CP1_400 & \multirow{2}{*}{400} & 13.8 & \multirow{2}{*}{13.8} & \multirow{2}{*}{$28 \%$} & \multirow{2}{*}{0.0071} & 2.35 & \multirow{2}{*}{2.65} & \multirow{2}{*}{$86.3 \%$} \\
\hline CP2_400 & & 13.7 & & & & 2.95 & & \\
\hline CP1_600 & \multirow{2}{*}{600} & 8.3 & \multirow{2}{*}{7.8} & \multirow{2}{*}{$59 \%$} & \multirow{2}{*}{0.0146} & 0.53 & \multirow{2}{*}{0.48} & \multirow{2}{*}{$97.5 \%$} \\
\hline CP2_600 & & 7.4 & & & & 0.43 & & \\
\hline
\end{tabular}

It is worth mentioning that, given the small dimensions of the specimens, it was assumed that the total heating time was sufficient to obtain homogenization of the temperature in the specimen. This hypothesis can be easily proved through theoretical analysis. In addition, it is worth mentioning the work of Chang et al. [48], where the authors adopted a constant external temperature for 1.5 to 2.5 hours for complete temperature homogenization in $15 \times 30 \mathrm{~cm}$ specimens. In the present study, the volume of the specimen is approximately $15 \%$ of that used by Chang et al. [48] and, therefore, a period of $30 \mathrm{~min}$ would be more than enough for this homogenization, justifying the hypothesis assumed.

After heating and properly cooled, the specimens were tested in compression. The tests were performed with a loading rate of $0.05 \mathrm{~mm} / \mathrm{min}$ up to rupture, using a servo-hydraulic actuator MTS model 204.63 with a load capacity of $100 \mathrm{kN}$. A pair of displacement transducers coupled to the specimen with the aid of acrylic rings was used to determine the strains. All information was collected automatically throughout the test. The objective of this step was to obtain the concrete stress-strain diagrams for specific temperatures.

The behavior of steel bars after being subjected to moderate temperatures was also investigated, following a procedure similar to that adopted for concrete. Six samples of $150 \mathrm{~mm}$ from the bars were tested in tension for ambient condition and after exposure to $250^{\circ} \mathrm{C}$ and $500{ }^{\circ} \mathrm{C}$ for $30 \mathrm{~min}$ (same furnace used for the concrete specimens), with two samples for each condition. No special preparation was made for the samples, which were tested under displacement control at a rate of $5 \mathrm{~mm} / \mathrm{min}$ on a universal testing machine model MTS 311 with a capacity of $1000 \mathrm{kN}$. The test was carried out without any additional external instrumentation and the measurements were only the total displacement of the actuator and the applied force. This strategy proved to be sufficient for a simple comparison between the different conditions.

\subsection{Stage II}

In Stage II, cylindrical reinforced concrete specimens with $15 \mathrm{~cm}$ in diameter, $30 \mathrm{~cm}$ in height and with $3 \mathrm{~cm}$ of cover were tested, divided into 5 groups according to the thermal loading time: 0 (room temperature, for control), 30, 60, 90 and $120 \mathrm{~min}$. Despite the milder fire consideration in the present work, the times were chosen in order to 
follow those observed in normative recommendations for a standard fire. The longitudinal reinforcement adopted for all samples was the same, comprised of four $10 \mathrm{~mm}$ diameter CA-50 ribbed bars, distributed uniformly in the perimeter. For each of the thermal loading groups from 0 to $90 \mathrm{~min}$, two specimens were made with only two ties spaced $20 \mathrm{~cm}$ and two others with three stirrups spaced $10 \mathrm{~cm}$, as shown in Figure 2a. Due to the occurrence of explosive spalling during heating for the configuration with two ties and high thermal loading times, the $120 \mathrm{~min}$ group had only two specimens with three ties tested. It is worth noting that the ties were used in an attempt to simulate the usual conditions i) with absence or few ties and ii) with usual spacing. The study of ties spacing that could provide greater gains in strength and ductility due to confinement is not scope of the work. For the thermal loading, an approximately linear heating rate was adopted, with a ramp between 4 and $5{ }^{\circ} \mathrm{C} / \mathrm{min}$, aiming to reproduce a milder loading condition, normally experienced in cases with low ventilation and low fire load. As pointed out by Chang et al. [48], results of fire tests on concrete columns [49] indicate heating rates of 2 to $4{ }^{\circ} \mathrm{C} / \mathrm{min}$ for temperatures in the range of 250 to $750{ }^{\circ} \mathrm{C}$. The use of constant rates represents a simplification, also adopted by Chang et al. [48]. The equipment used for heating was an Brasimet electric muffle with a maximum capacity of $1200{ }^{\circ} \mathrm{C}$, as shown in Figure 1b. Seeking to reduce the heat exchange between the ends of the specimens and, thus, approach the problem to an one-dimensional heat flow condition during thermal loading, the ends of the specimens were thermally insulated with the aid of a $5 \mathrm{~cm}$-thick stone wool insulation, as shown in Figure $2 \mathrm{~b}$. After heating, the specimens were removed from the oven and cooled naturally at room temperature, in the same fashion as in Stage I. It is important to highlight that specimens were free to expand and retract during heating and cooling processes, in an attempt to minimize associated thermal stresses. Table 2 presents a summary of the tests performed in Stage II, with the appropriate nomenclatures and test conditions. The parameters related to the results, also presented in the table, will be described in Section 3.2.

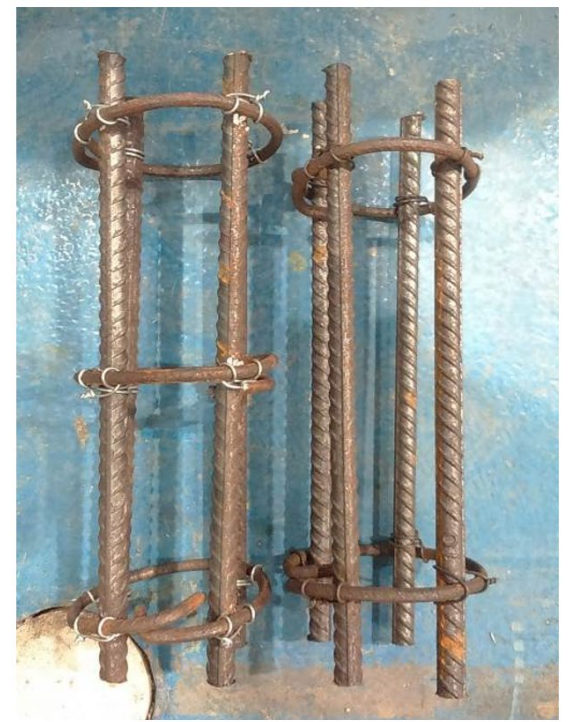

(a)

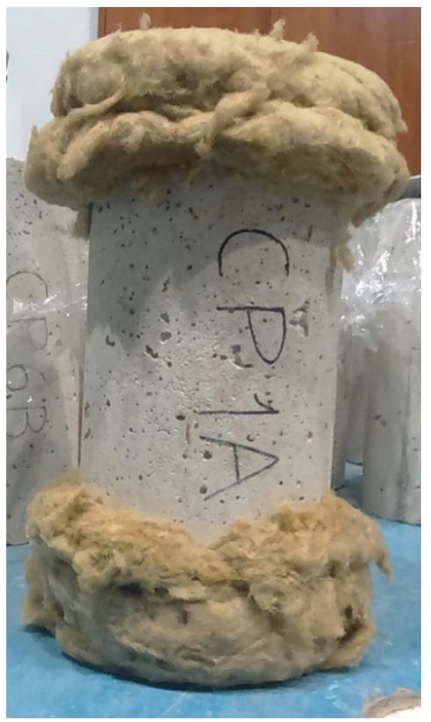

(b)

Figure 2. Preparation of Stage II specimens: a) reinforcement configuration with two and three ties; b) stone wool thermal insulation applied at the ends.

The compression tests were performed on a Controls model 50-C46Z00 testing machine, with a load capacity of $2000 \mathrm{kN}$ up to rupture at a mechanical loading rate of $0.1 \mathrm{~mm} / \mathrm{min}$. As in Stage I, displacement transducers coupled to the specimen with acrylic rings were used to determine the strains during the test. Once again, all test information was automatically recorded by the data acquisition system. The objective of Stage II was to simulate a mild fire with a constant thermal load rate and considering typical fire duration times. The stress-strain relations obtained in Stage I were used for the theoretical analysis of the results of Stage II, where the cross-sectional temperature distribution is non-uniform and, therefore, the mechanical response varies along the radius. 
Table 2. Identification (ID) of stub columns of Stage II and summary of results.

\begin{tabular}{|c|c|c|c|c|c|c|c|}
\hline \multirow{2}{*}{ ID } & $\begin{array}{c}\text { Time of } \\
\text { exposure }\end{array}$ & $\begin{array}{c}\text { Number of } \\
\text { ties }\end{array}$ & $\begin{array}{c}\text { Maximum } \\
\text { Temperature }\end{array}$ & Spalling? & $\sigma_{u}$ & $\sigma_{u, \text { mean }}$ & $\left(\sigma_{u 20}-\sigma_{u}\right) / \sigma_{u 20}$ \\
\hline & $(\min )$ & - & $\left({ }^{\circ} \mathrm{C}\right)$ & (Yes/No) & (MPa) & (MPa) & - \\
\hline CP1_0_2 & 0 & 2 & 20 & No & 23.55 & \multirow{2}{*}{22.09} & \multirow{2}{*}{-} \\
\hline CP2_0_2 & 0 & 2 & 20 & No & 20.63 & & \\
\hline CP1_0_3 & 0 & 3 & 20 & No & 20.04 & \multirow{2}{*}{19.80} & \multirow{2}{*}{-} \\
\hline CP2_0_3 & 0 & 3 & 20 & No & 19.55 & & \\
\hline CP1_30_2 & 30 & 2 & 170 & No & 22.04 & \multirow{2}{*}{20.38} & \multirow{2}{*}{$7.8 \%$} \\
\hline $\mathrm{CP} 2 \_30 \_2$ & 30 & 2 & 169 & No & 18.71 & & \\
\hline CP1_30_3 & 30 & 3 & 169 & No & 16.83 & \multirow{2}{*}{18.34} & \multirow{2}{*}{$7.4 \%$} \\
\hline $\mathrm{CP} 2 \_30 \_3$ & 30 & 3 & 185 & No & 19.85 & & \\
\hline CP1_60_2 & 60 & 2 & 315 & No & 18.45 & \multirow{2}{*}{18.19} & \multirow{2}{*}{$17.7 \%$} \\
\hline CP2_60_2 & 60 & 2 & 318 & No & 17.92 & & \\
\hline CP1_60_3 & 60 & 3 & 315 & No & 15.21 & \multirow{2}{*}{15.30} & \multirow{2}{*}{$22.7 \%$} \\
\hline CP2_60_3 & 60 & 3 & 313 & No & 15.39 & & \\
\hline CP1_90_2 & 90 & 2 & 408 & Yes & - & \multirow{2}{*}{-} & \multirow{2}{*}{ - } \\
\hline CP2_90_2 & 90 & 2 & 400 & Yes & - & & \\
\hline CP1_90_3 & 90 & 3 & 422 & No & 17.86 & \multirow{2}{*}{16.41} & \multirow{2}{*}{$17.1 \%$} \\
\hline CP2_90_3 & 90 & 3 & 423 & No & 14.96 & & \\
\hline CP1_120_3 & 120 & 3 & 422 & Yes & - & \multirow{2}{*}{15.92} & \multirow{2}{*}{$19.6 \%$} \\
\hline CP2_120_3 & 120 & 3 & 496 & No & 15.92 & & \\
\hline
\end{tabular}

\section{RESULTS AND DISCUSSIONS}

\subsection{Stage I}

Regarding the color of the concrete, the specimens heated to $200{ }^{\circ} \mathrm{C}$ did not present any change, remaining with their original gray color. For the samples submitted to $400{ }^{\circ} \mathrm{C}$, the color remained gray, but with pink points. Finally, the specimens heated to $600{ }^{\circ} \mathrm{C}$ showed a color change to a darker gray with reddish streaks, which indicates friability - liable to crumble or disintegrate - and high water suction [50]. Figure 3 illustrates the changes in the color of the plain concrete.

Table 1 shows the values of compressive strength and modulus of elasticity obtained in the tests for the concrete specimens and Figures $4 \mathrm{a}$ and $4 \mathrm{~b}$ show, respectively, the variation of $f_{\mathrm{c} \theta} / f_{\mathrm{c} 20}$ and $E_{\mathrm{cs} \theta} / E_{\mathrm{cs} 20}$ with temperature, where $f_{\mathrm{c} \theta}$ is the compressive strength for a temperature $\theta, f_{\mathrm{c} 20}$ is strength at room temperature, $E_{\mathrm{cs} \theta}$ is the secant module at a temperature $\theta$ and $E_{\mathrm{cs} 20}$ is the secant module at room temperature - obtained as the slope of the secant line between 0 to $40 \%$ of the strength. As expected, it is observed that both the residual compressive strength and the modulus are reduced as the temperature of exposure increases, while the peak deformations increased. With respect to the strength, there was a reduction of approximately $15 \%$ for a temperature of $200{ }^{\circ} \mathrm{C}, 30 \%$ for $400{ }^{\circ} \mathrm{C}$ and $60 \%$ for $600{ }^{\circ} \mathrm{C}$ with respect to the control specimens. These retentions of residual strength are in accordance with the values found by Chan et al. [51] for normal strength concretes, as well as the values presented in Eurocode 2 [34]. 


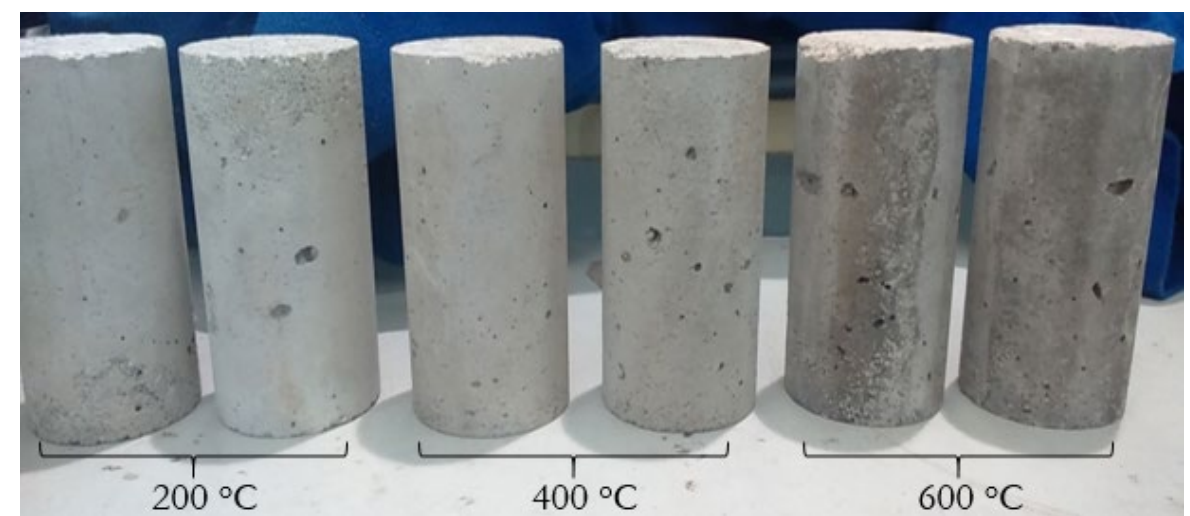

Figure 3. Changes of color of plain concrete specimens exposed to temperatures of 200,400 and $600{ }^{\circ} \mathrm{C}$.

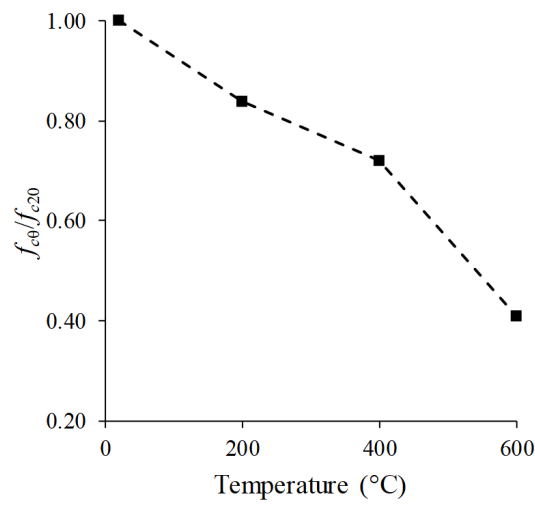

(a)

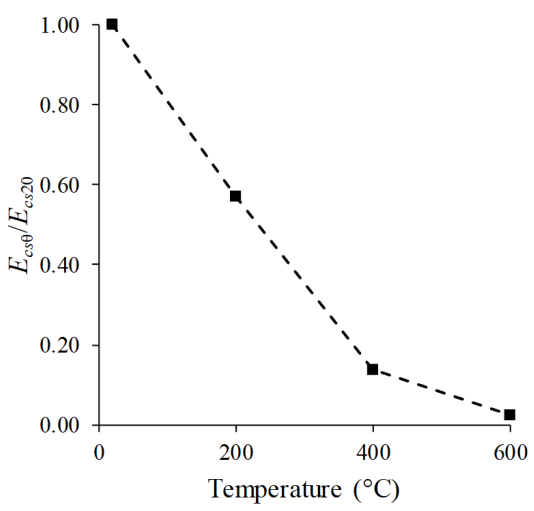

(b)

Figure 4. Retention of properties with temperature of exposure: a) compressive strength; b) secant modulus of elasticity.

Figure 5a illustrates the stress-strain relations obtained from the compression tests for the concrete specimens of Stage I. The curves for each temperature showed good consistency, and it is possible to observe, in addition to the erosion of strength already reported, reductions in modulus of elasticity and increases in the peak and ultimate strains with increasing temperatures. The stress-strain curves obtained in this stage will be used in Section 3.3, to perform theoretical correlation with the results obtained in the short columns of Stage II. Figure $5 \mathrm{~b}$ shows the force $v s$ actuator displacement results for the steel bars tested in tension. From the similarity between the responses, it is possible to observe that the behavior of the steel is not affected after exposure to temperatures up to $500{ }^{\circ} \mathrm{C}$.

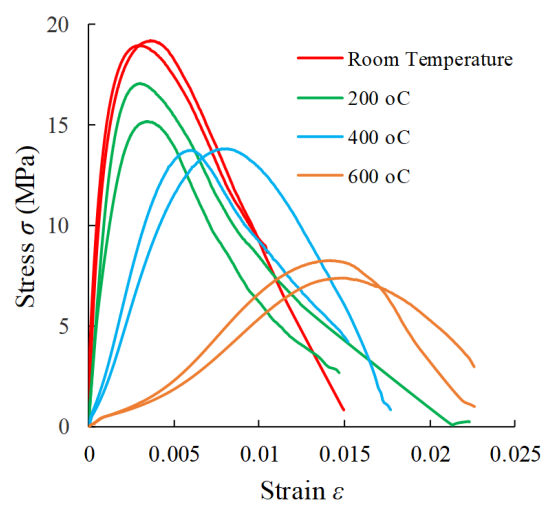

(a)

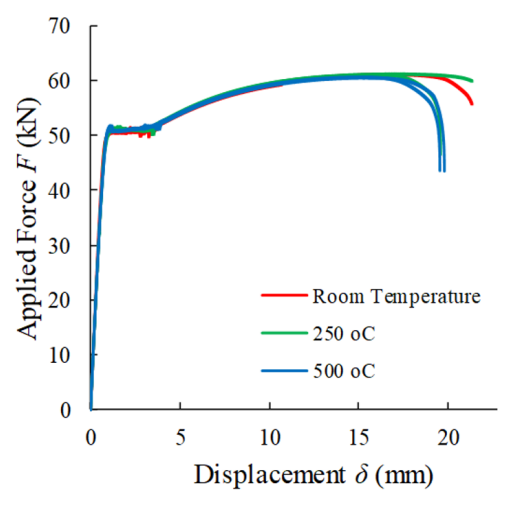

(b)

Figure 5. Response of materials after exposure to different temperatures: a) stress-strain relations for plain concrete; b) forcedisplacement curves for steel. 


\subsection{Stage II}

During thermal loading, some specimens showed spalling from temperatures over $400{ }^{\circ} \mathrm{C}$, as shown in Table 2 . They had their cross section reduced and, therefore, were not subjected to compression tests, resulting in a reduction in the number of samples tested. The phenomenon occurred, consistently, for specimens with 2 ties. On the other hand, confirming expectations, samples containing 3 ties showed better control against spalling, associated with the confinement provided by the transverse reinforcement. Figure 6 illustrates the samples after explosive spalling.

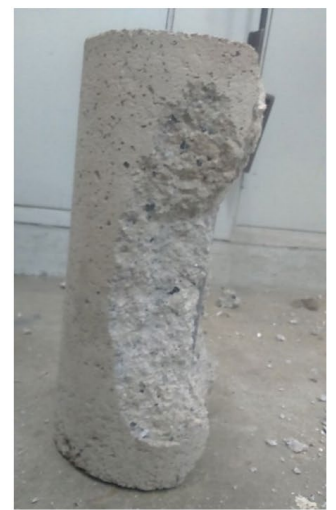

(a)

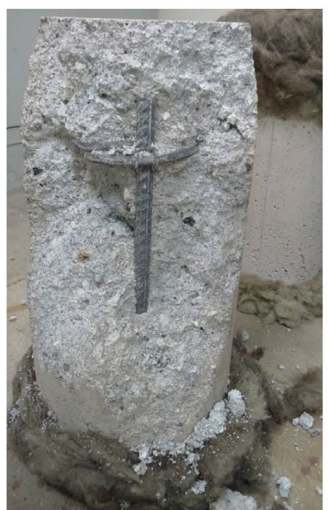

(b)

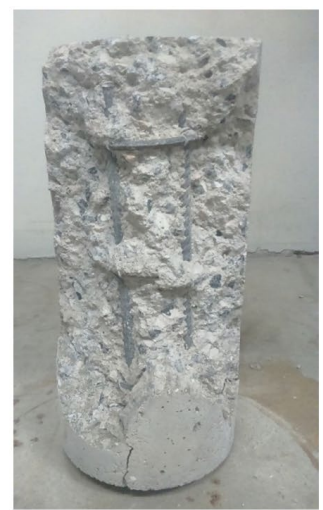

(c)

Figure 6. Spalling of specimens: a) CP1_90_2 $\left(408^{\circ} \mathrm{C}\right)$; b) CP2_90_2 $\left(400^{\circ} \mathrm{C}\right)$; c) CP1_120_3 $\left(422^{\circ} \mathrm{C}\right)$.

Figure 7 shows the failure modes of some of the short columns tested, where it is possible to observe the formation of surface cracks and the diagonal rupture pattern that occurred in some cases. Figure $8 \mathrm{a}$ and $8 \mathrm{~b}$ show the curves for average stress $\sigma_{\mathrm{c}}$ vs strain $\varepsilon$ of the short columns tested for conditions with two and three ties, respectively, where the average stress was obtained by dividing the applied force by the total area of the cross section. It can be noted some variability in the strengths of the two groups for similar exposure temperatures, as well as in the peaks of strain. However, in general, samples with 2 ties failed in a fragile manner with greater strength, expect for one of the specimens exposed for $30 \mathrm{~min}$. Despite contributing to the confinement of the central portion of concrete and to a more ductile rupture at higher temperatures, it is known that the steel reinforcement introduces porous interfaces between steel and concrete, which can locally reduce the strength and influence the transport of water inside the heated concrete, increasing the risk of spalling [16]. In addition, the intermediate tie may have restricted the free expansion of concrete during heating, introducing thermal-induced damage. However, only analysis by microscopy or tomography could reveal in greater detail the extent of the resulting damage and the presence of the porous area. Figure 9 presents a comparison between the strengths of specimens with 2 and 3 ties for different exposure times, from where it is possible to observe more clearly the trend of columns with three stirrups to exhibit lower capacity than those with 2 ties. From Table 2 and Figure 9 , it is worth noting that the reduction in strength in relation to the original condition reaches the order of $20 \%$ for exposure times of $60 \mathrm{~min}$, with apparent stabilization for longer periods of time. It is also important to note the variation in the results, which may be associated with the material's own variability in terms of mechanical properties and imperfections.

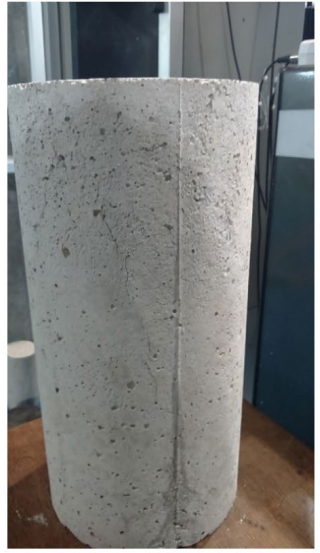

(a)

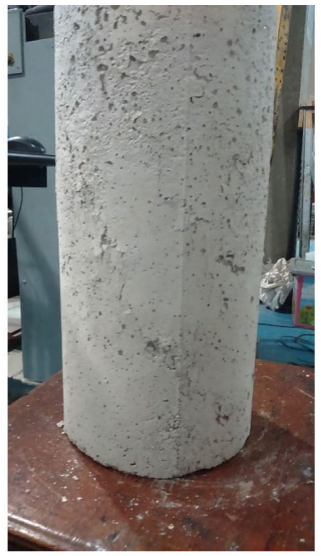

(b)

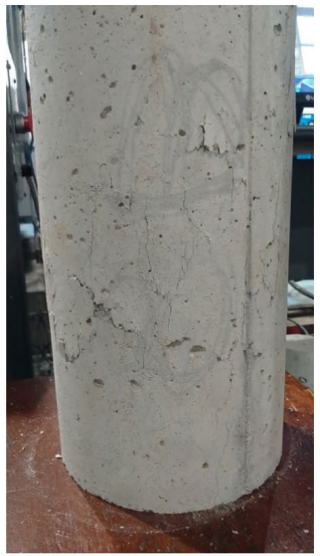

(c)

Figure 7. Examples of failure modes of reinforced concrete stub columns: a) CP1_30_2; b) CP1_90_3; c) CP2_120_3. 


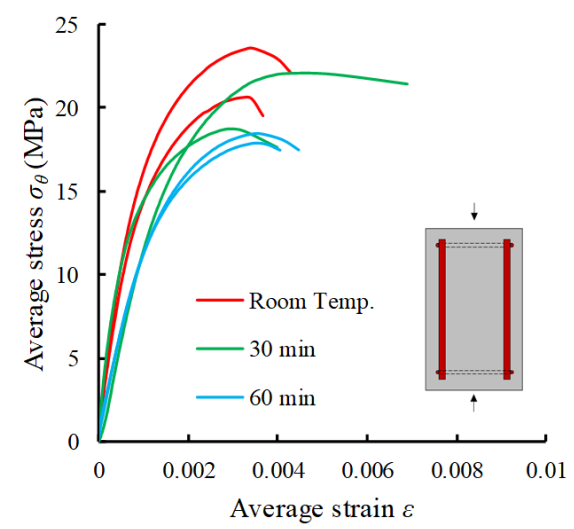

(a)

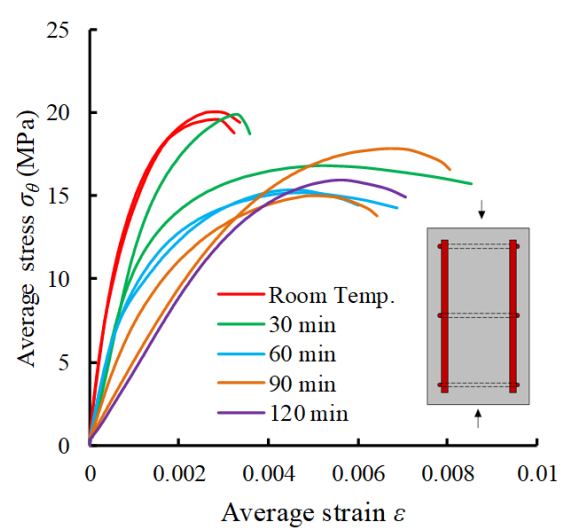

(b)

Figure 8. Average stress vs stress curves for reinforced concrete stub columns: a) two ties; b) three ties.

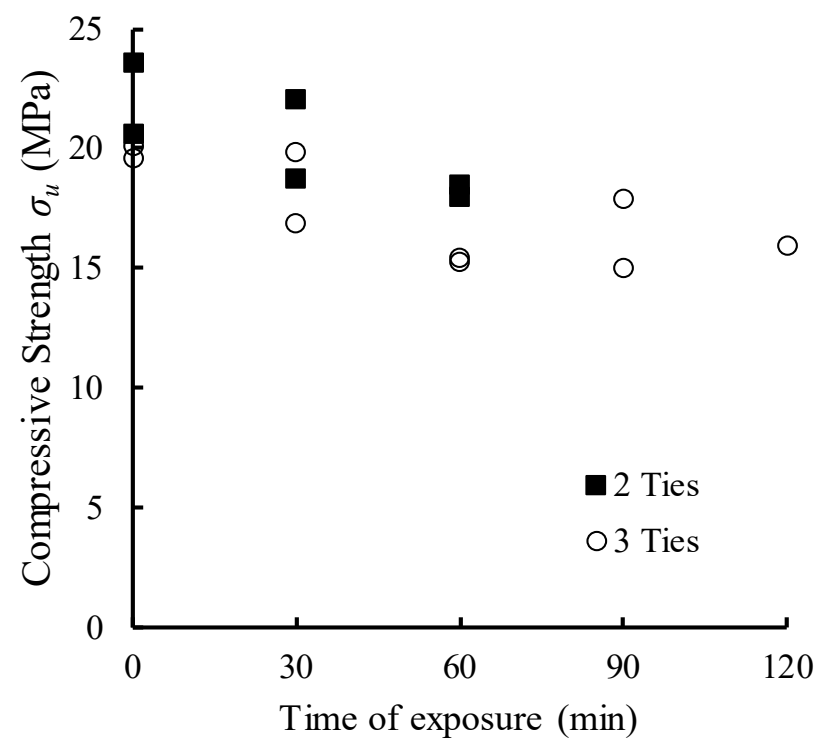

Figure 9. Strength of stub columns with two or three lateral ties for different times of exposure.

\subsection{Comparison with Theoretical Model}

For the theoretical prediction, the first step is to determine the cross-sectional temperature distribution with time. For this, a one-dimensional heat transfer analytical model was used (long cylinders without internal heat generation) and considering the problem of imposing a temperature at the outer surface. Thus, the solution can be obtained using the variable separation technique for a given initial temperature distribution in the cylinder [52]. As the temperature in the case in question is variable, an incremental solution was adopted where, for each increment of $20^{\circ} \mathrm{C}$ applied to the surface, the profile obtained in the previous step was considered. In a simplified way, it was assumed that the thermal conductivity coefficient of the concrete, $k$, the specific heat, $c_{p}$, and the specific mass, $\rho$, remained constant throughout the test, with values $k=1.3 \mathrm{~W} /\left(\mathrm{m}^{\circ} \mathrm{C}\right), c_{p}=1000 \mathrm{~J} /\left(\mathrm{kg}{ }^{\circ} \mathrm{C}\right)$ and $\rho=2400 \mathrm{~kg} / \mathrm{m}^{3}$, respectively. It was also admitted that the initial temperature in the cylinder was uniform and equal to $20^{\circ} \mathrm{C}$, the heating rate was $4{ }^{\circ} \mathrm{C} / \mathrm{min}$ and that the temperature in the air inside the muffle was equal to the temperature on the outer surface of the concrete cylinder. With these data, it was possible to obtain the temperature distribution shown in Figure 10a. 


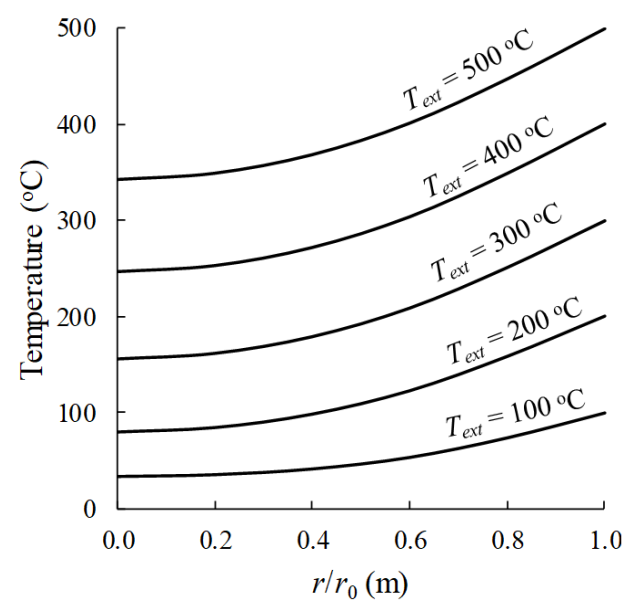

(a)

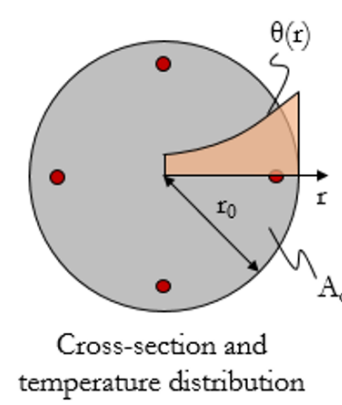

(b)

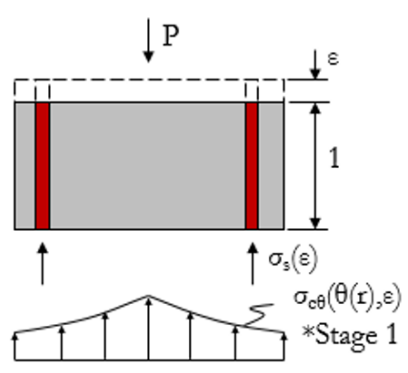

Elevation and stress distribution

Figure 10. Theoretical model: a) temperature distribution with the relative distance between center and outer face $\left(r / r_{0}\right)$; b) stress distribution as a function of specific strain and temperature profile.

With the profile determined, the next step is to determine the average stress vs. strain curve for the column. In this case, for each imposed strain value, the stresses at each point of the concrete cross section were estimated from the interpolation of the stress-strain curves $\left(\sigma_{\mathrm{c} \theta}-\varepsilon\right)$ idealized for each temperature, according to the Equation 1 recommended in the Model Code 2010 [53].

$\sigma_{c \theta}(\theta, \varepsilon)=f_{c \theta} \frac{k_{c} \cdot\left(\frac{\varepsilon}{\varepsilon_{c l \theta}}\right)-\left(\frac{\varepsilon}{\varepsilon_{c l \theta}}\right)^{2}}{1+\left(k_{c}-2\right)\left(\varepsilon / \varepsilon_{c l \theta}\right)}$

where $f_{\mathrm{c} \theta}$ and $\varepsilon_{\mathrm{c} 1 \theta}$ are respectively the compressive strength and strain for the peak of stress for a given temperature $\theta$, $k_{\mathrm{c}}$ is a plasticity number defined as the ratio between the initial tangent module, $E_{\mathrm{ci}}$, and $E_{\mathrm{cl}}=f_{\mathrm{c} \theta} / \varepsilon_{\mathrm{c} 1 \theta}$. In the present work, the parameters adopted in the idealized curves were adjusted to the experimental results obtained in Stage I (see Table 1), with an additional reduction factor multiplied to the concrete compressive strength $k_{\text {esc }}=0.8$ to incorporate the scale effect [54] and possible changes in the sample's collapse mechanisms by the introduction of the metallic reinforcement. On the other hand, the stiffness and the strain at peak were maintained according to Table 1, with $k_{c}$ values equal to $5.40,3.98,1.93$ and 1.83 , respectively, for temperatures of $20{ }^{\circ} \mathrm{C}, 200{ }^{\circ} \mathrm{C}, 400{ }^{\circ} \mathrm{C}$ and $600{ }^{\circ} \mathrm{C}$. In the case of intermediate temperatures, the parameters were interpolated. Moreover, it was verified through tests carried out with steel that the residual properties were not affected for temperatures up to $500{ }^{\circ} \mathrm{C}$. Therefore, the ideal model is bilinear, with elastic modulus $E_{\mathrm{s}}=200 \mathrm{GPa}$ and yield strength $f_{\mathrm{y}}=500 \mathrm{MPa}$. Finally, the force mobilized $P$ as a function of an imposed strain can be obtained as shown in Figure 10b and the average stress $\sigma_{\mathrm{c}}$ is calculated according to the sectional analysis defined in Equation 2 below:

$\sigma_{c}(\varepsilon)=\frac{P(\varepsilon)}{A_{c}}=\frac{k_{e s c} \int_{0}^{r_{0}} 2 \pi \sigma_{c \theta}(\theta(r), \varepsilon) d r+A_{s} \sigma_{s}(\varepsilon)}{A_{c}}$

where $r_{0}$ is the cylinder radius, $\theta$ is the temperature inside the cylinder (function of radius), $A_{\mathrm{s}}=4 \times 78.5 \mathrm{~mm}^{2}$ is the total reinforcing steel area, $A_{\mathrm{c}}$ is the concrete area and $\sigma_{\mathrm{s}}=\varepsilon E_{\mathrm{s}}<f_{\mathrm{y}}$ is the stress at steel. In the calculation, thermal stresses associated with gradients or eventual restraints were not considered.

Figures 11a-e present the comparisons between the theoretical and experimental predictions for the various conditions investigated. Comparing the results, it is possible to conclude that, taking into account the simplicity of the analysis, the correlation between experiment and theoretical model is good, although in some cases the predictions were above the experimental values, especially for longer exposure times. Figure $11 \mathrm{f}$ shows the ratio between the strengths obtained experimentally and using the theoretical model, indicating a mean of 0.916 and a coefficient of variation $(\mathrm{CoV})$ of $9.31 \%$. The differences for longer exposure times are explained by a weakening of the outer layers in direct contact with the hot air and by the presence of thermal stresses and damage - effects not captured in sectional analysis. Nevertheless, it is important to note that none of the samples reached a surface temperature of $500{ }^{\circ} \mathrm{C}$ and the use of 
the established method of the $500^{\circ} \mathrm{C}$ isotherm would be extremely against safety, as it would lead to the false conclusion that no strength loss would be experienced by the columns with respect to the original condition. Therefore, questions can be raised regarding its applicability at moderate temperatures.

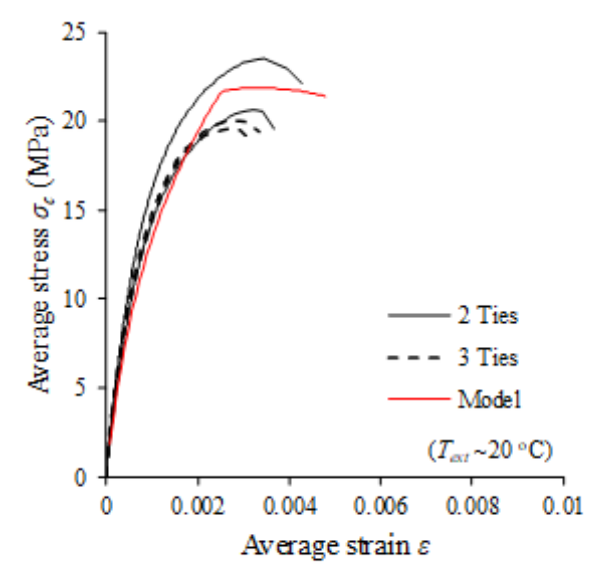

(a)

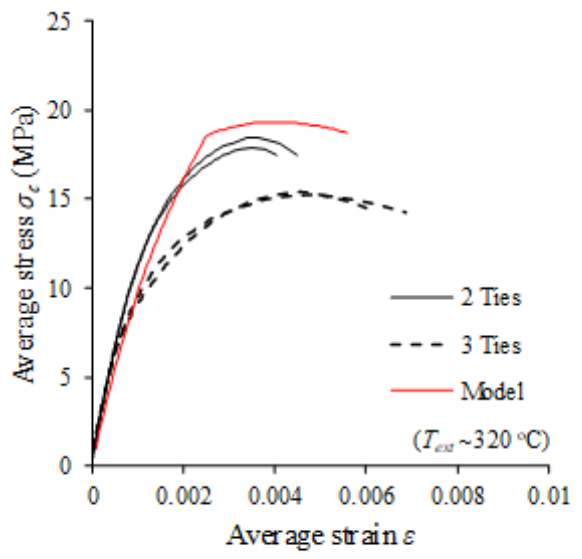

(c)

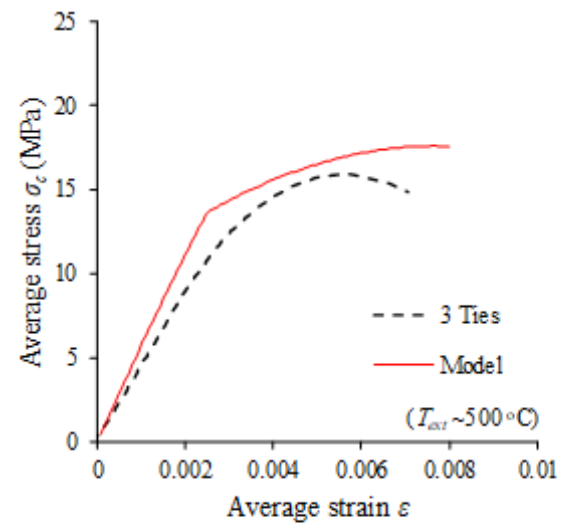

(e)

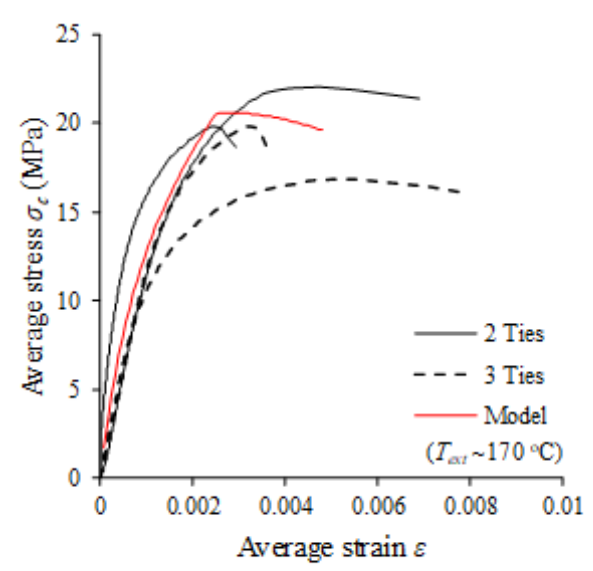

(b)

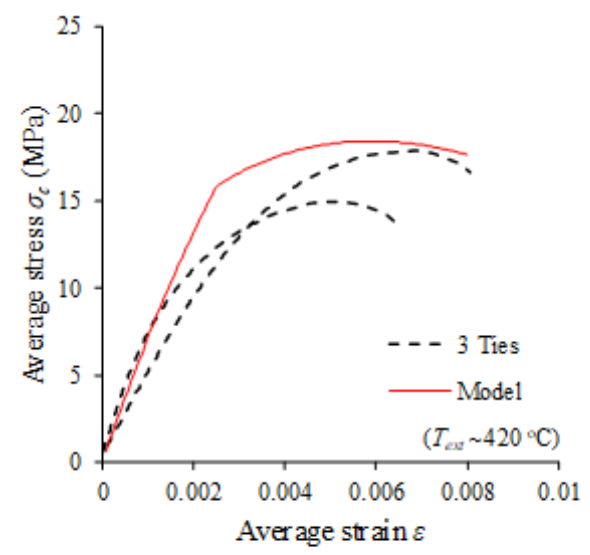

(d)

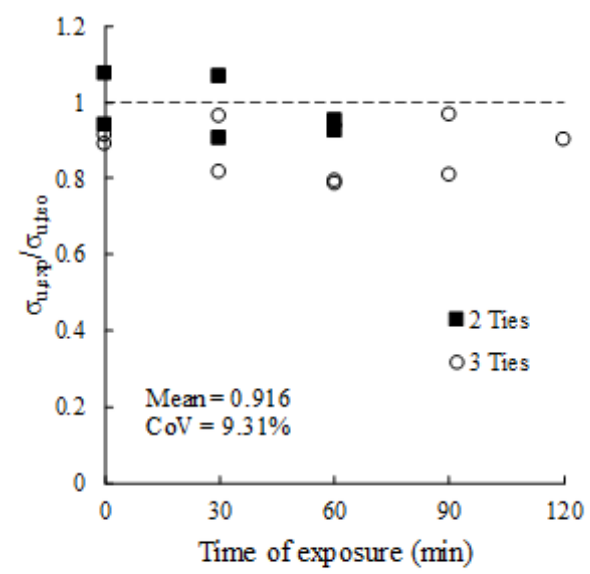

(f)

Figure 11. Comparison between experimental and analytical results: a) room temperature; b) 30 min of exposure; c) 60 min of exposure; d) $90 \mathrm{~min}$ of exposure; e) $120 \mathrm{~min}$ of exposure; f) ratio between experimental and theoretical strengths $\left(\sigma_{\mathrm{u}, \text { exp }} / \sigma_{\mathrm{u}, \text { teo }}\right)$. 


\section{CONCLUSIONS}

The conclusions obtained from the following work are:

- he experimental results showed that the residual strength of the concrete investigated in the study (low mechanical strength) is affected by temperature and that the reductions are in good agreement with those recommended in the Eurocode 2 [34]. The reductions reached $60 \%$ for concretes subjected to $600{ }^{\circ} \mathrm{C}$ for $30 \mathrm{~min}$, in relation to the ambient condition;

- The spalling phenomenon was observed during thermal loading, even at temperatures of around $400{ }^{\circ} \mathrm{C}$, which may result in a reduction in the cross-sectional area of the structural element and direct exposure of reinforcing steel to fire. The adoption of intermediate ties proved to be adequate in preventing the phenomenon, as pointed out in the literature [44]-[46];

- Short columns with intermediate ties presented lower strength, but, in general, greater ductility. This difference was observed for exposure times of 30 and $60 \mathrm{~min}$ and must be associated with the appearance of thermal-induced stresses and damage caused by the restraints to expansion associated to the introduction of the intermediate tie. This result contrasts with the observations in the literature for concretes with higher mechanical strengths, which indicate an increase in residual strength due to the action of confinement. It is noteworthy that the transverse reinforcement rate adopted in the present work is low (compatible with spacing and diameters used in practice) and, therefore, a reduced confinement action would also be expected;

- The theoretical model, although simple, proved to be adequate for theoretical prediction of behavior. Differences can be explained by the influence of thermal stresses and imperfections generated by the introduction of metallic reinforcement (not covered in the analysis). A mean of 0.916 was obtained for the ratios between experimental and theoretical strengths;

- Taking into account that none of the tested stub columns reached a surface temperature of $500{ }^{\circ} \mathrm{C}$, but that strength reductions of up to $20 \%$ were obtained in relation to the ambient condition, the application of the $500{ }^{\circ} \mathrm{C}$ isotherm method would lead to a strength estimate against safety and, therefore, its applicability for moderate temperatures must be better evaluated.

\section{ACKNOWLEDGEMENTS}

All tests were performed at the Structures and Materials Laboratory of the Pontifical Catholic University of Rio de Janeiro. This study was partially funded by the Coordenação de Aperfeiçoamento de Pessoal de Nível Superior CAPES, finance code 001 - and by the Brazilian agencies FAPERJ and CNPq.

\section{REFERENCES}

[1] P. K. Mehta and P. J. Monteiro, Concrete: Microstructure, Properties and Materials. New York: McGraw-Hill Education, 2017.

[2] I. A. Fletcher, S. Welch, J. L. Torero, R. O. Carvel, and A. Usmani, "Behaviour of concrete structures in fire," Therm. Sci., vol. 11, no. 2, pp. 37-52, 2007.

[3] W. M. Lin, T. D. Lin, \& L. J, "Microstructures of fire-damaged concrete”, Mater. J., vol. 93, no. 3, pp. 199-205, 1996.

[4] B. Fernandes, A. M. Gil, F. L. Bolina, and B. F. Tutikian, "Microestrutura do concreto submetido a altas temperaturas: alterações físico-químicas e técnicas de análise," Rev. IBRACON Estrut. Mater., vol. 10, no. 4, pp. 838-863, 2017.

[5] E. Annerel and L. Taerwe, "Revealing the temperature history in concrete after fire exposure by microscopic analysis," Cement Concr. Res., vol. 39, no. 12, pp. 1239-1249, 2009.

[6] J. C. Liu, K. H. Tan, and Y. Yao, "A new perspective on nature of fire-induced spalling in concrete," Constr. Build. Mater., vol. 184, pp. 581-590, 2018.

[7] C. G. Han, Y. S. Hwang, S. H. Yang, and N. Gowripalan, "Performance of spalling resistance of high performance concrete with polypropylene fiber contents and lateral confinement," Cement Concr. Res., vol. 35, no. 9, pp. 1747-1753, 2005.

[8] M. Zeiml, D. Leithner, R. Lackner, and H. A. Mang, "How do polypropylene fibers improve the spalling behavior of in-situ concrete," Cement Concr. Res., vol. 36, no. 5, pp. 929-942, 2006.

[9] Y. S. Heo, J. G. Sanjayan, C. G. Han, and M. C. Han, "Synergistic effect of combined fibers for spalling protection of concrete in fire," Cement Concr. Res., vol. 40, no. 10, pp. 1547-1554, 2010.

[10] I. B. Topçu and C. Karakurt, "Properties of reinforced concrete steel rebars exposed to high temperatures," Res. Lett. Mater. Sci., vol. 2008, pp. 1-4, 2008.

[11] R. Chijiiwa, Y. Yoshida, R. Uemori, H. Tamehiro, K. Funato, \& Y. Horii, "Development and practical application of fire-resistant steel for buildings", Nippon Steel Technical Report, pp. 47-55, 199. 
[12] G. A. Khoury, "Effect of fire on concrete and concrete structures," Prog. Struct. Eng. Mater., vol. 2, no. 4, pp. 429-447, 2000.

[13] P. D. Morley and R. Royles, "Response of the bond in reinforced concrete to high temperatures," Mag. Concr. Res., vol. 35, no. 123, pp. 67-74, 1983.

[14] C. H. Chiang and C. L. Tsai, "Time-temperature analysis of bond strength of a rebar after fire exposure," Cement Concr. Res., vol. 33, no. 10, pp. 1651-1654, 2003.

[15] A. F. Bingöl and R. Gül, "Residual bond strength between steel bars and concrete after elevated temperatures," Fire Saf. J., vol. 44, no. 6, pp. 854-859, 2009.

[16] J. H. Chung and G. R. Consolazio, "Numerical modeling of transport phenomena in reinforced concrete exposed to elevated temperatures," Cement Concr. Res., vol. 35, no. 3, pp. 597-608, 2005.

[17] A. H. Shah and U. K. Sharma, "Fire resistance and spalling performance of confined concrete columns," Constr. Build. Mater., vol. 156, pp. 161-174, 2017.

[18] K. A. Zaidi, U. K. Sharma, and N. M. Bhandari, "Effect of temperature on uni-axial compressive behavior of confined concrete," Fire Saf. J., vol. 48, pp. 58-68, 2012.

[19] V. Kodur and R. Mcgrath, "Fire endurance of high strength concrete columns," Fire Technol., vol. 39, no. 1, pp. 73-87, 2003.

[20] K. H. Tan and Y. Yao, "Fire resistance of four-face heated reinforced concrete columns," J. Struct. Eng., vol. 129, no. 9, pp. 1220$1229,2003$.

[21] V. K. R. Kodur, F. P. Cheng, T. C. Wang, and M. A. Sultan, "Effect of strength and fiber reinforcement on fire resistance of highstrength concrete columns," J. Struct. Eng., vol. 129, no. 2, pp. 253-259, 2003.

[22] J. M. Franssen, B. Zhao, and T. Gernay, "Experimental tests and numerical modelling on slender steel columns at high temperatures," J. Struct. Fire Eng., vol. 7, no. 1, pp. 30-40, 2016.

[23] Y. H. Chen, Y. F. Chang, G. C. Yao, and M. S. Sheu, "Experimental research on post-fire behaviour of reinforced concrete columns," Fire Saf. J., vol. 44, no. 5, pp. 741-748, 2009.

[24] J. M. Franssen and J. C. Dotreppe, "Fire tests and calculation methods for circular concrete columns," Fire Technol., vol. 39, no. 1, pp. 89-97, 2003.

[25] F. Ali, A. Nadjai, and S. Choi, "S., "Numerical and experimental investigation of the behavior of high strength concrete columns in fire," Eng. Struct., vol. 32, no. 5, pp. 1236-1243, 2010.

[26] International Organization for Standardization, Fire Resistance Tests - Elements of Building Construction, ISO-834, 1975.

[27] M. J. Terro, "Numerical modeling of the behavior of concrete structures in fire," ACI Struct. J., vol. 95, pp. 183-193, 1998.

[28] R. B. Caldas, J. B. M. Sousa Jr., and R. H. Fakury, "Interaction diagrams for reinforced concrete sections subjected to fire," Eng. Struct., vol. 32, no. 9, pp. 2832-2838, 2010.

[29] J. C. Dotreppe, J. M. Franssen, and Y. Vanderzeipen, "Calculation method for design of reinforced concrete columns under fire conditions," ACI Struct. J., vol. 96, no. 1, pp. 9-18, 1999.

[30] V. K. R. Kodur, T. C. Wang, and F. P. Cheng, "Predicting the fire resistance behaviour of high strength concrete columns," Cement Concr. Compos., vol. 26, no. 2, pp. 141-153, 2004.

[31] S. Bratina, B. Čas, M. Saje, and I. Planinc, "Numerical modelling of behaviour of reinforced concrete columns in fire and comparison with Eurocode 2," Int. J. Solids Struct., vol. 42, no. 21-22, pp. 5715-5733, 2005.

[32] D. Di Capua and A. R. Mari, "Nonlinear analysis of reinforced concrete cross-sections exposed to fire," Fire Saf. J., vol. 42, no. 2 , pp. 139-149, 2007.

[33] S. F. El-Fitiany and M. A. Youssef, "Assessing the flexural and axial behaviour of reinforced concrete members at elevated temperatures using sectional analysis," Fire Saf. J., vol. 44, no. 5, pp. 691-703, 2009.

[34] European Committee for Standardization, Design of Concrete Structures, Part 1-2: Structural Fire Design, Eurocode $2,2004$.

[35] V. K. R. Kodur, B. Yu, and M. M. S. Dwaikat, "A simplified approach for predicting temperature in reinforced concrete members exposed to standard fire," Fire Saf. J., vol. 56, pp. 39-51, 2013.

[36] T. T. Lie, Structural Fire Protection (ASCE Manuals and Reports on Engineering Practice, 78). New York: American Society of Civil Engineers, 1992.

[37] U. Wickström, A Very Simple Method for Estimating Temperature in Fire Exposed Concrete Structures (Fire Technology Technical Report SP-RAPP, 46). Swedish National Testing Institute, 1986, pp. 186-194.

[38] European Committee for Standardization, Actions on Structures - Part 1-2: General Actions - Actions on Structures Exposed to Fire, Eurocode 1, 2002.

[39] A. Law, J. Stern-Gottfried, M. Gillie, and G. Rein, "The influence of travelling fires on a concrete frame," Eng. Struct., vol. 33, no. 5, pp. 1635-1642, 2011.

[40] X. Dai, S. Welch, and A. Usmani, "A critical review of "travelling fire" scenarios for performance-based structural engineering," Fire Saf. J., vol. 91, pp. 568-578, 2017. 
[41] J. Stern-Gottfried and G. Rein, "Travelling fires for structural design-Part I: literature review," Fire Saf. J., vol. 54, pp. 74-85, 2012.

[42] D. Rush and D. Lange, "Towards a fragility assessment of a concrete column exposed to a real fire-Tisova Fire Test," Eng. Struct., vol. 150, pp. 537-549, 2017.

[43] A. Law, J. Stern-Gottfried, M. Gillie, and G. Rein, "The influence of travelling fires on a concrete frame," Eng. Struct., vol. 33, no. 5, pp. 1635-1642, 2011.

[44] M. J. Terro and S. A. Hamoush, "Effect of confinement on siliceous aggregate concrete subjected to elevated temperatures and cyclic heating," Mater. J., vol. 94, no. 2, pp. 83-89, 1997.

[45] B. Wu, X. P. Su, H. Li, and J. Yuan, "Effect of high temperature on residual mechanical properties of confined and unconfined highstrength concrete," Mater. J., vol. 99, no. 4, pp. 399-407, 2002.

[46] K. A. Zaidi, U. K. Sharma, and N. M. Bhandari, "Effect of temperature on uni-axial compressive behavior of confined concrete," Fire Saf. J., vol. 48, pp. 58-68, 2012.

[47] J. M. Watts Jr. and M. E. Kaplan, "Fire risk index for historic buildings," Fire Technol., vol. 37, no. 2, pp. 167-180, 2001.

[48] Y. F. Chang, Y. H. Chen, M. S. Sheu, and G. C. Yao, "Residual stress-strain relationship for concrete after exposure to high temperatures," Cement Concr. Res., vol. 36, no. 10, pp. 1999-2005, 2006.

[49] M. S. Sheu, Y. H. Chen, Y. F. Chang, and M. D. Yeh, Seismic Resistance of Fired-Damaged Interior RC Columns, Project No. 092301070000-G1020. Taipei, Taiwan: ABRI, Ministry of Interior, 2004.

[50] N. R. Short, J. A. Purkiss, and S. E. Guise, "Assessment of fire damaged concrete using colour image analysis," Constr. Build. Mater., vol. 15, no. 1, pp. 9-15, 2001.

[51] Y. N. Chan, G. F. Peng, and M. Anson, "Residual strength and pore structure of high-strength concrete and normal strength concrete after exposure to high temperatures," Cement Concr. Compos., vol. 21, no. 1, pp. 23-27, 1999.

[52] Y. Cengel, Heat and Mass Transfer: Fundamentals and Applications. New York: McGraw-Hill Higher Education, 2014.

[53] Fédération Internationale du Béton, Fib Model Code for Concrete Structures 2010, 2013.

[54] A. Carpinteri, G. Ferro, and I. Monetto, "Scale effects in uniaxially compressed concrete specimens," Mag. Concr. Res., vol. 51, no. 3, pp. 217-225, 1999.

Author contributions: EHBL: conceptualization, data analysis, writing; DCTC: conceptualization, writing, funding acquisition, supervision.

Editors: Ricardo Carrazedo, José Luiz Antunes de Oliveira e Sousa, Guilherme Aris Parsekian. 